\title{
Free fatty acid profiles of fermented beverages made from ewe's milk
}

\author{
Agata REGUŁA* \\ Department of Animal Products Technology, Agricultural University in Cracow, ul. Balicka 122, \\ Kraków, Poland
}

Received 4 April 2006 - Accepted 30 November 2006

\begin{abstract}
The aim of the present study was to estimate the level of the free fatty acids (FFA) in fermented beverages (yogurt, bioyogurt, sour milk and kefir) made from ewe's milk. Identification and quantification of FFA were performed by gas chromatography. It was found that FFA content in the fermented beverages was significantly affected by the kind of starter culture. Yogurt, as well as bioyogurt, possessed more lauric, myristic, palmitic, stearic and oleic acids than kefir and sour milk. The inverse trend was found for acetic acid level. In the beverages produced using mesophilic cultures the amount of this compound was higher than in beverages containing thermophilic bacteria. Due to the fact that acetic acid was predominant among FFA, the highest total FFA was found for kefir and sour milk. It was also observed that the amount of most of the FFA on the last day of the storage period was lower than on the first day of analysis.
\end{abstract}

free fatty acid profile / fermented beverage / ewe's milk

摘要 - 绵羊奶发酵乳饮料中游离脂肪酸的特性研究。本文采用气相色谱法定性和定量研究 了发酵乳饮料 (酸奶、活性乳、酸牛奶、开菲尔) 中游离脂肪酸的含量。实验证明发酵剂 的种类能够显著地影响乳饮料中游离脂肪酸的含量。酸奶和活性乳与酸牛奶和开菲尔相比 较, 前两种乳饮料中月桂酸、肉豆冦酸、棕梱酸、硬脂酸和油酸含量高于后两种乳饮料, 而乙酸含量的变化则呈相反的趋势。由嗜温菌发酵剂发酵的乳饮料中乙酸含量高于由嗜热 菌发酵剂发酵的乳饮料。由于乙酸是游离脂肪酸中的主要成分, 因而酸牛奶和开菲尔的总 脂肪酸含量最高。研究还发现在咜藏期内，发酵乳饮料中多数游离脂肪酸的含量是败藏期 的最后一天低于第一天。

游离脂肪酸的特性 / 发酵乳饮料 / 绵羊奶

Résumé - Profils des acides gras libres dans les laits fermentés au lait de brebis. Le but de la présente étude était d'estimer le niveau des acides gras libres (AGL) dans des boissons fermentées (yaourt, bioyogourt, lait caillé et kéfir) au lait de brebis. L'identification et la quantification de AGL ont été réalisées par chromatographie en phase gazeuse. On a constaté que le type de ferment lactique affectait de manière significative le contenu en AGL dans les boissons fermentées. Le yaourt aussi bien que le bioyogourt présentait une quantité plus importante d'acides laurique, myristique, palmitique, stéarique et oléique que le kéfir et le lait caillé. La tendance inverse a été trouvée pour le niveau d'acide acétique. Dans les boissons qui ont été produites en utilisant la culture mésophile, la quantité de ce composé était plus élevée que dans les boissons qui contenaient les bactéries thermophiles. Étant donné que l'acide acétique était prédominant parmi les AGL, la quantité la plus importante d'AGL a été trouvée pour le kéfir et le lait caillé. On a également observé que la plupart des AGL était trouvée en plus faible quantité le dernier jour de la période de stockage par rapport au premier jour de l'analyse.

acide gras libre / lait fermenté / lait de brebis

*Corresponding author (通讯作者): agatreg@ poczta.onet.pl 


\section{Abbreviations used:}

FFA: free fatty acids; SCFA: short-chain fatty acids; C2 - acetic acid; C4 - butyric acid; C6 - caproic acid; C8 - caprylic acid; C10 - capric acid; C12 - lauric acid; C14 - myristic acid; C16 - palmitic acid; C18 - stearic acid; C18:1 - oleic acid.

\section{INTRODUCTION}

Milk fat plays an important role in fermented beverage manufacturing: it affects taste perception and the final volume of curd, while also limiting syneresis. As a result of lipolysis, free fatty acids are liberated. These compounds, especially shortchain fatty acids (SCFA), are involved in forming the sensorial quality of products [3]. Because of their strong aroma, and low sensory threshold, at high concentrations some of these acids can lead to an undesired flavor of fermented milk. The nutritional aspect of fatty acids cannot be omitted: some of these compounds (acetic and butyric acids) show antibiotic and anticancer properties $[12,19]$.

Lactic acid bacteria possess enzymes that are able to hydrolyze mono-, di- and triacylglycerols. The activity of the lipases depends strongly on the genera and bacteria species, as well as on the temperature and presence of calcium and magnesium ions. However, the activity of bacterial enzymes is crucial, and it is not only the level of milk fat degradation that is affected by this phenomenon: also determined by this are the kind of milk, fat content and access of enzymes to the substrate. Also very important is the preliminary treatment of the raw material, because all technological treatments (cooling, homogenization and stirring) that cause the destruction of the milk fat globule membrane can lead to the risk of excessive lipolysis [6].

Due to the fact that variation in free fatty acids (FFA) content gives rise to changes in the organoleptic and nutritional qualities of milk products, it is important to evaluate the level of these compounds in fermented milk beverages. Until now, there have been only a few reports concerning this subject $[2,4]$. The recent studies were performed mainly on cow's milk $[14,16]$ and there is also limited information about the free fatty acid profile in fermented beverages made from ewe's milk. The aim of the present study was to evaluate the differences in FFA levels for four fermented beverages (yogurt, bioyogurt, kefir and sour milk) produced from ewe's milk. The second factor in the present research was the storage period.

\section{MATERIALS AND METHODS}

\subsection{Material}

Ewe's milk was collected five times in the morning from Polish mountain ewes in the spring. The types of the fermented milks and starters used are presented in Table I.

Table I. Types of the fermented milks and starters used.

\begin{tabular}{|c|c|}
\hline Type of fermented milk & Characteristic of starter culture \\
\hline $\begin{array}{l}\text { Yogurt - YC-180 } \\
\text { (Chr. Hansen) }\end{array}$ & Streptococcus thermophilus, Lactobacillus delbrueckii ssp. bulgaricus \\
\hline $\begin{array}{l}\text { Bioyogurt - ABT-1 } \\
\text { (Chr. Hansen) }\end{array}$ & $\begin{array}{c}\text { Streptococcus thermophilus, Lactobacillus acidophilus, } \\
\text { Bifidobacterium species }\end{array}$ \\
\hline $\begin{array}{l}\text { Kefir - D } \\
\text { (Rhodia Food Biolacta) }\end{array}$ & Lactobacillus sp., Lactococcus sp. and yeast \\
\hline $\begin{array}{l}\text { Sour milk }-\mathrm{CH}-\mathrm{N}-11 \\
\text { (Chr. Hansen) }\end{array}$ & $\begin{array}{c}\text { Lactococcus lactis ssp. cremoris, Lactococcus lactis ssp. lactis, } \\
\text { Lactococcus lactis ssp. diacetylactis, Leuconostoc mesenteroides ssp. } \\
\text { cremoris }\end{array}$ \\
\hline
\end{tabular}




\subsection{Milk analysis}

In raw milk, dry matter content was assessed by air-drying at $105^{\circ} \mathrm{C}$ for $2.5 \mathrm{~h}$, the protein content was analyzed from the crude nitrogen according to the Kjeldahl method and the total fat content was evaluated using the Gerber method [1]. The milk density was measured using a densitometer. Lactose content was determined by enzymatic methods using commercial kits provided by Boehringer (Mannheim, Germany).

\subsection{Fermented beverages}

Ewe's milk was heated to $95^{\circ} \mathrm{C}$ for $5 \mathrm{~min}$ and then cooled: to $45^{\circ} \mathrm{C}$ (for yogurt), to $38^{\circ} \mathrm{C}$ ( for bioyogurt), and to $22^{\circ} \mathrm{C}$ (for sour milk and kefir). The DVS (Direct Vat System) cultures were inoculated into the milk at a rate of $0.04 \mathrm{~g} \cdot \mathrm{L}^{-1}$ (yogurt), $0.08 \mathrm{~g} \cdot \mathrm{L}^{-1}$ (bioyogurt) and $0.06 \mathrm{~g} \cdot \mathrm{L}^{-1}$ (sour milk) and DVI (Direct Vat Inoculation) culture at a rate of $0.04 \mathrm{~g} \cdot \mathrm{L}^{-1}$ (kefir). The incubation process was carried out as follows: yogurt at $43{ }^{\circ} \mathrm{C}$, bioyogurt at $38{ }^{\circ} \mathrm{C}$, sour milk and kefir at $22{ }^{\circ} \mathrm{C}$ until the $\mathrm{pH}$ of the inoculated milks fell to 4.6. After the incubation period the fermented milks were stored at $4{ }^{\circ} \mathrm{C}$ for $14 \mathrm{~d}$. Experiments were carried out five times.

\subsection{Free fatty acid analysis}

Identification and quantification of FFA were based on the method described by Huerta-Gonzalez and Wilbey [7]. Each of the samples $(10.00 \mathrm{~g})$ was weighed and mixed with $10 \mathrm{~mL}$ ethanol, $1 \mathrm{~mL}$ of $2.5 \mathrm{~mol} \cdot \mathrm{L}^{-1}$ sulfuric acid and $1 \mathrm{~mL}$ of internal standard solution $\left(0.5 \mathrm{mg} \cdot \mathrm{L}^{-1}\right.$ each of $\mathrm{C} 5, \mathrm{C} 13$ and C17). Lipid extraction was performed using diethyl ether:heptan $(1: 1 \mathrm{v} / \mathrm{v})$. Neutral lipid components were extracted on aminopropyl columns (previously conditioned with heptane) with chloroform:2-propanol $(2: 1 \mathrm{v} / \mathrm{v})$. FFA were eluted from the column with $20 \mathrm{~mL} \cdot \mathrm{L}^{-1}$ formic acid in diethyl ether. A fraction containing underivatized FFA was injected directly into the gas chromatograph equipped with a "Nukol" capillary column (length $30 \mathrm{~m}$ ). The carrier gas's (helium) flow rate was $20 \mathrm{~mL} \cdot \mathrm{min}^{-1}$, and the temperature was raised from: $70{ }^{\circ} \mathrm{C}$ to
Table II. Free fatty acids in raw ewe's milk.

\begin{tabular}{lc}
\hline $\begin{array}{l}\text { Free fatty } \\
\text { acids }\end{array}$ & $\begin{array}{c}\mathrm{X} \pm \mathrm{S}_{\mathrm{e}} \\
\left(\mu \mathrm{g} \cdot \mathrm{g}^{-1} \text { fat }\right)\end{array}$ \\
\hline $\mathrm{C}_{2}$ & $4452.3 \pm 225.60$ \\
$\mathrm{C}_{4}$ & $6.38 \pm 0.41$ \\
$\mathrm{C}_{6}$ & $10.24 \pm 0.34$ \\
$\mathrm{C}_{8}$ & $12.27 \pm 0.89$ \\
$\mathrm{C}_{10}$ & $38.4 \pm 2.85$ \\
$\mathrm{C}_{12}$ & $29.6 \pm 1.11$ \\
$\mathrm{C}_{14}$ & $73.00 \pm 0.90$ \\
$\mathrm{C}_{16}$ & $203.6 \pm 17.67$ \\
$\mathrm{C}_{18}$ & $36.4 \pm 6.80$ \\
$\mathrm{C}_{18: 1}$ & $42.7 \pm 11.80$ \\
TOTAL & $4904.8 \pm 246.97$ \\
\hline
\end{tabular}

$200{ }^{\circ} \mathrm{C}$ at $5^{\circ} \mathrm{C} \cdot \mathrm{min}^{-1}$, then held at $200{ }^{\circ} \mathrm{C}$ for $30 \mathrm{~min}$.

\subsection{Statistical analysis}

Statistical analysis was carried out using Statistica 6.0 software. Differences among fresh fermented beverages were investigated using one-way analysis of variance. To establish the presence or absence of significant difference in the FFA contents of the fermented beverages, considering the kind of starter culture and the time of the storage period, two-factor analysis of variance was done.

\section{RESULTS AND DISCUSSION}

The physicochemical composition of the raw ewe's milk was as follows: density was $1.0352 \pm 0.001 \mathrm{~g} \cdot \mathrm{cm}^{-3}$, protein $(5.74 \pm$ $0.02)$, fat $(6.48 \pm 0.08)$ and lactose $(4.59 \pm$ $0.04)$. The free fatty acid (FFA) profile of the raw milk is presented in Table II. Total FFA content was approximately two times higher than the value reported by Kondyli and Katsiari [9]. This difference was affected by the very high level of acetic acid, which was predominant in the milk evaluated in the present study. It is considered that this compound can originate from milk plasma as a product of changes in non-fat 

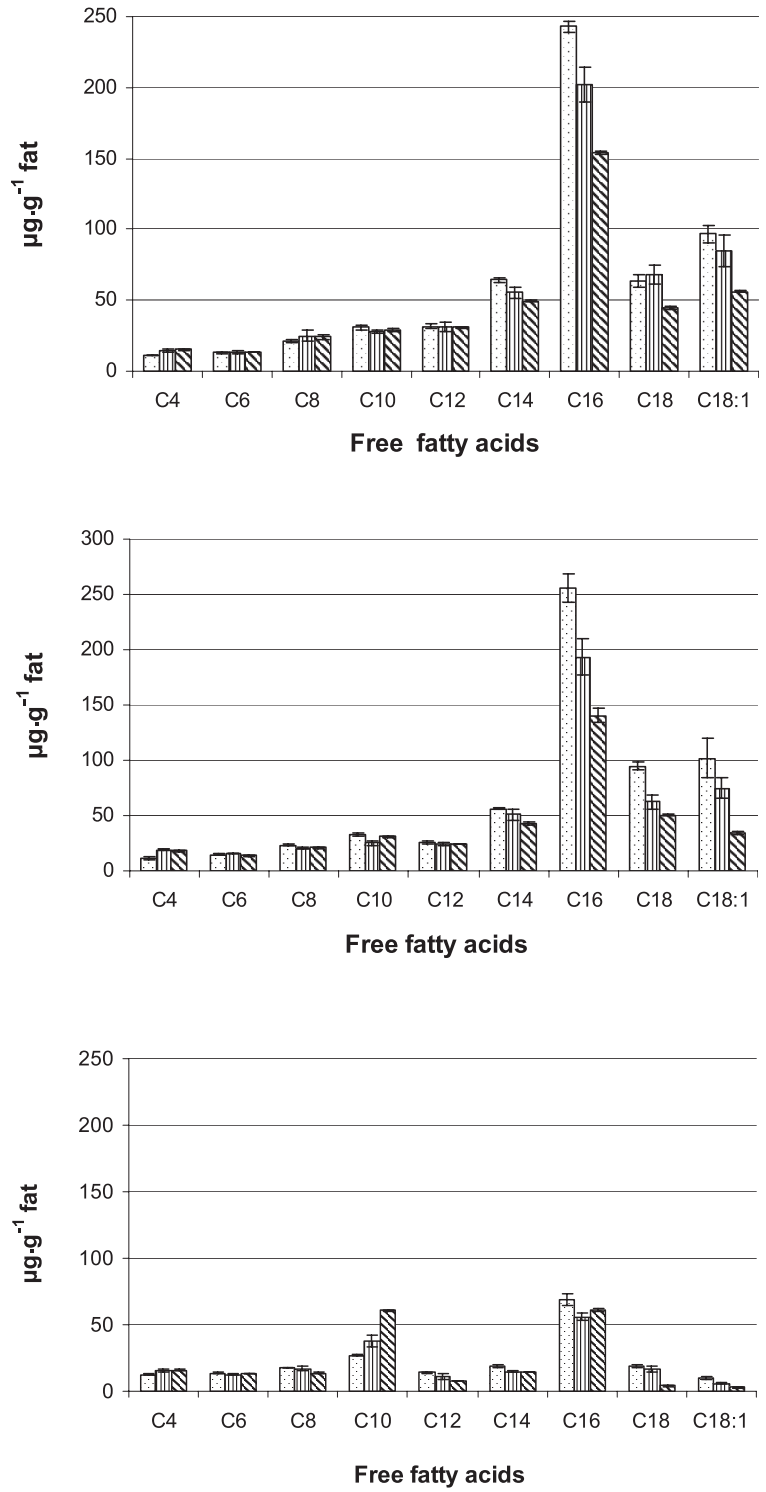

Figure 1. Free fatty acid profile of yogurt during storage period

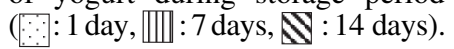

Figure 2. Free fatty acid profile of bioyogurt during storage period ( $: 1$ day, $\mathbb{m}: 7$ days, $\mathbf{N}: 14$ days).

Figure 3. Free fatty acid profile of sour milk during storage period ( $\because$ : 1 day, $\|$ m $: 7$ days, $\mathbf{N}: 14$ days).

compounds. Acetic acid is a basic substrate to $\mathrm{C} 4-\mathrm{C} 16$ fatty acid synthesis. It is also possible that such a high content in raw milk, as estimated in the present study, was due to an incomplete synthesis process. FFA (C4-C18:1) content was in agreement with the value found by Diaz et al. [5].
The starter cultures used in the present study considerably altered the FFA profile of the fermented beverages. The changes in the C4-C18:1 acid content of the four different products are presented in the Figures 1-4. Due to the fact that acetic acid is considered mainly as a product of various metabolic 


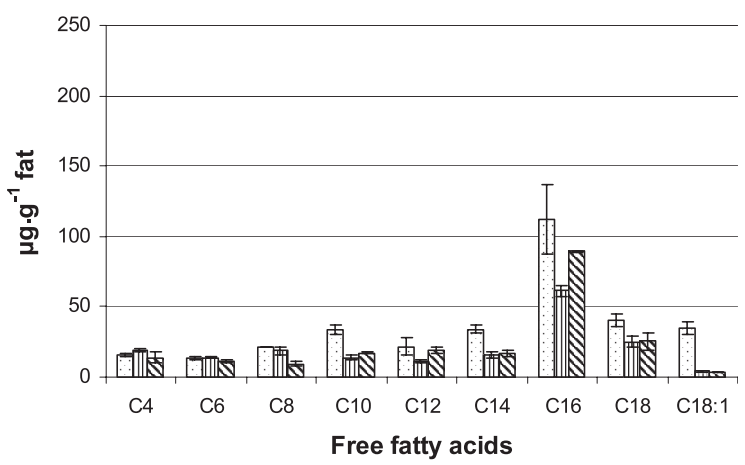

Figure 4. Free fatty acid profile of kefir during storage period ( 1 day, $[1$ l) 7 days, $\mathbf{N}: 14$ days).

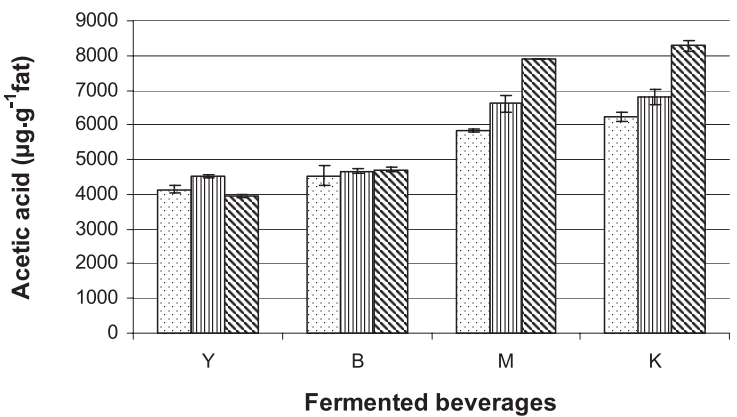

Figure 5. Acetic acid content in yogurt (Y), bioyogurt (B), sour milk (S) and kefir $(\mathrm{K})$ during storage period ( $: 1$ day, $\mathbb{\text { III }}: 7$ days, $\mathbf{\$}: 14$ days).

routes and because of its much greater level in comparison with other fatty acids, the amount of this compound is presented separately in Figure 5. The fermented beverages differed statistically significantly $(P \leq 0.05)$ in acetic acid content. It was observed that beverages which contained mesophilic culture (kefir and sour milk) possessed 27$33.5 \%$ more of this compound than the products in which thermophilic starters were used (yogurt and bioyogurt). The presence of acetic acid in the fermented beverages is related to the metabolism of sugar and amino acids rather than to fat hydrolysis $[3,11]$. Also, the fact that free fatty acids present in the raw material are potential substrates for bacterial enzymes should not be omitted. The complexity of the hydrolytic changes in the milk components as caused by the mixed starter culture does not permit the main source of acetic acid to be identified unequivocally.

The common character of all the freshly fermented products was an increase in $\mathrm{C} 4$, $\mathrm{C} 6$ and $\mathrm{C} 8$ in comparison with their level in raw milk. The augmentation in these free short-chain fatty acids (SCFA) could be explained by the fact that these compounds are esterificated in triacylglycerols mainly at the sn-3 position, which is easily hydrolyzed by bacterial lipases. Lipolytic enzymes of lactobacilli and lactococci also show substrate specificity in relation to SCFA [13]. There are conflicting results regarding lipolytic activity of lactic acid bacteria. Baranowska [2] reports that single cultures of Lactobacillus acidophilus and Lactobacillus delbrueckii ssp. bulgaricus liberated more volatile FFA (C4-C8) in milk than Streptococcus thermophilus. The reverse results were shown by Tamime and Robinson [17], who report that milk inoculated with Streptococcus thermophilus possessed more volatile FFA than milk in which Lactobacillus was used. The same authors indicate that mixed culture caused more intensive lipolysis than single culture, which is a result of the stimulation effect and cooperation phenomena between these microorganisms.

In the present study the level of the free fatty acids $\mathrm{C} 10, \mathrm{C} 12$ and $\mathrm{C} 14$ in fresh 
fermented beverages was found to be reduced in comparison with their content in raw milk. One exceptional case was yogurt, in which a slight increase in lauric acid was found. Bacterial lipases possess weak specificity in regard to the linkage in position sn-2 in triacylglycerols, where more than $50 \%$ of the acids C10, C12 and C14 are esterificated. Walstra and Jenness [18] and Mistry et al. [10] report that this percentage can vary depending on the kind of milk. The drop in the amount of these compounds in the present study could be related to their utilization by microorganisms. It can also not be excluded that these compounds could have reacted with alcohols (ethanol) formed by the breakdown of acetaldehyde or derived from alcohol fermentation. Distinct and statistically significant $(P \leq 0.01)$ differences were found between mesophilic and thermophilic cultures concerning palmitic, stearic and oleic acids. Both fresh yogurt and bioyogurt were characterized by an increase in the content of these acids ranging from $19.5-164 \%$, while kefir and sour milk contained $13.5-89 \%$ less of the same acids in comparison with raw milk. Kamaly et al. [8] reported that lipases of Lactococcus lactis ssp. lactis and Lactococcus lactis ssp. cremoris possess the highest activity at $37^{\circ} \mathrm{C}$. There is also another important factor affecting the functionality of lipolytic enzymes, which is environment $\mathrm{pH}$. Lipolytic enzymes of mesophilic cocci also show substrate specificity, especially for shortchain fatty acids. In the literature there are conflicting data concerning lipolytic activity of yogurt cultures. Rašić and Vučurović [15] demonstrated the decrease in longchain fatty acids in yogurt, while Rao and Reddy [14] found an increase in stearic and oleic acids in milk inoculated with Streptococcus thermophilus and Lactobacillus delbrueckii ssp. bulgaricus.

The research work of some authors confirms an increase in FFA in fermented beverages during the storage period $[2,4,16]$. However, the results of these studies do not present the profile of FFA but only indicate the total level of FFA, which can give only a somewhat limited view of changes in these compounds. On the basis of our results, it could be surmised that the kind of culture affects the direction and intensity of changes in FFA profile during the storage period. It was shown that the level of most of the FFA on the last day of storage was lower than on the first day of analysis. However, distinctly exceptional cases were capric acid in sour milk and acetic acid in kefir, bioyogurt and sour milk. The amount of acetic acid was predominant, and as a result, the increase in this compound's level simultaneously affected the considerable increase in total FFA in kefir, sour milk and bioyogurt.

\section{CONCLUSION}

Fermented beverages made from ewe's milk differed significantly in the level of free fatty acids. Thermophilic bacteria cause more intensive liberation of the acids $\mathrm{C} 12, \mathrm{C} 14, \mathrm{C} 16, \mathrm{C} 18$ and $\mathrm{C} 18: 1$ than mesophilic microorganisms. Kefir and sour milk are characterized by higher acetic acid content than yogurt and bioyogurt.

During the storage period the intensity and direction of changes in FFA level differed depending on the starter culture. Fourteen-day-old fermented beverages were characterized by lower content of most of the FFA than 1-day-old beverages.

\section{REFERENCES}

[1] AOAC, Official methods of analysis, AOAC International Press, Arlington, 1990.

[2] Baranowska M., Content of volatile fatty acids in milk acidified by yoghurt cultures, in: Proc. of the IXth International Scientific Session Progress in Dairy Technology Technique and Organization, Olsztyn, Poland, 19-20 February 2004, pp. 149-158

[3] Beshkova D., Simova E., Frengova G., Simov Z., Production of flavour compounds by starter cultures, J. Ind. Microbiol. Biotech. 20 (1998)180-186.

[4] Bonczar G., Wszoek M., Siuta A., The effects of certain factors on the properties of yoghurt made from ewe's milk, Food Chem. 79 (2002) 85-91.

[5] Diaz J.R., Peris C., Rodriguez M., Molina M.P., Fernandez N., Effect of milking pipeline height on machine milking efficiency 
and milk quality in sheep, J. Dairy Sci. 87 (2004) 1675-1683.

[6] Evers J.M., The milk fat globule membranecompositional and structural changes post secretion by the mammary secretory cell, Int. Dairy J. 14 (2004) 661-674.

[7] Huerta-Gonzalez L., Wilbey R.A., Determination of free fatty acids produced in filledmilk emulsions as a result of the lipolytic activity of lactic acid bacteria, Food Chem. 72 (2001) 301-307.

[8] Kamaly K.M. Takayama K, Marth E., Acylglycerol acylhydrolase (lipase) activities of Streptococcus lactis, Streptococcus cremoris, and their mutants, J. Dairy Sci. 73 (1990) 280-290.

[9] Kondyli E., Katsiari M.C., Fatty acid composition of raw ewe's milk of Boutsiko breed during lactation, Milchwissenschaft 57 (2002) 74-76.

[10] Mistry D., de Peters J., Medrano J., Comparative composition of total and sn-2 fatty acids in bovine and ovine milk fat, Lait 82 (2002) 255-259.

[11] Nakae T., Elliott J.A., Production of volatile fatty acids by some lactic acid bacteria. II. Selective formation of volatile fatty acids by degradation of amino acids, J. Dairy Sci. 48 (1965) 293-299.

[12] Parodi P., Anti-cancer agents in milk fat, Aust. J. Dairy Technol. 58 (2003) 114-118.
[13] Prieto B.,Franco I., Prieto J.G., Bernardo A., Carballo J., Proteolytic and lipolytic changes during the ripening of Leon raw cow's milk cheese, a Spanish traditional variety, Int. J. Food Sci. Technol. 37 (2002) 661-671.

[14] Rao D.R., Reddy J.C., Effect of lactic fermentation of milk on milk lipids, J. Food Sci. 49 (1984) 748-750.

[15] Rašić J., Vučurović N., Studies on free fatty acids in yoghurt made from cow's, ewe's and goat's milk, Milchwissenschaft 28 (1973) 220-222.

[16] Sady M., Grega T., Walczycka M., Bonczar G., Influence of amaranth seeds and oat grains addition on yoghurts quality and shelf life, Sci. Messenger of Lviv Natl Acad. 6 (2004) 231-240.

[17] Tamime A.Y., Robinson R.K., Yogurt, Science and Technology, Woodhead Publishing Ltd, Cambridge, England, 2000.

[18] Walstra P., Jenness R., Lipids in Dairy Chemistry and Physics, A Wiley-Interscience Publication, John Wiley \& Sons, New York, 1985.

[19] Wójtowski J., Danków R., Skrzypek R., Fahr R., The fatty acid profile in kefir from sheep, goat and cow milk, Milchwissenschaft 58 (2003) 633-635. 